\title{
The Effect of Over Consolidation Ratio on the Deformations of Tunnels Constructed in Clay Soils
}

\section{Kil Zeminlerde İnşa Edilen Tünellerdeki Deformasyonlara Așırı Konsolidasyon Oranının Etkisi}

\author{
Burak Görgün $^{1 *}$, Nazile Ural ${ }^{2}$ \\ Geliş / Received: 10/09/2021 \\ Revize / Revised: 27/09/2021 \\ Kabul / Accepted: 11/10/2021

\begin{abstract}
With the globalization of the world, it has become necessary to create new routes for transportation due to the decrease in usage areas for construction and accelerated living conditions. For these reasons, some of the road and railway routes selected for transportation are passed through tunnels. In addition, with the increase in population in metropolitan cities, necessitated transportation by rail systems so tunnel constructions became a necessity here. However, these tunnels made on clay soils can cause major problems. Due to these problems, routes change, construction projects cannot be completed, and even during tunnel construction, tunneling devices become stuck in the tunnel and become unusable. In this study, the deformations of tunnels made in clay soils with different over consolidation ratios were investigated by using Plaxis2D program, which analyzes with the finite element method. The tunnel model was created using the New Austrian Tunneling Method (NATM) and the deformations in the clay soil were determined under static and dynamic loading conditions.
\end{abstract}

Keywords- Over Consolidation Ratio, Tunnel, Clay, Plaxis

\section{$\overline{\mathbf{O Z Z}}$}

Dünyanın küreselleşmesiyle günümüzde yapılaşma için kullanım alanları azalması ve hızlanan yaşam koşulları sebebiyle ulaşım için yeni güzergahlar oluşturulması zorunlu hale gelmiştir. Bu nedenlerle ulaşım için seçilen yol ve demiryolu güzergahlarının bir kısmı tünellerle geçilmektedir. Ayrıca büyükşehirlerde nüfusun artması buralarda raylı sistemlerle taşımacılığı zorunlu kılmış ve buralarda da tünel inşaatları gereklilik haline dönüşmüştür. Ancak kil zeminlerde yapılan bu tünellerde büyük problemler ortaya çıkabilmektedir. Bu problemlerden dolayı güzergahlar değişmekte, inşaat projeleri tamamlanamamakta, hatta tünel yapımı esnasında tünel açma cihazları tünel içerisinde sıkışarak kullanılamaz hale gelmektedir. Bu çalışmada sonlu elemanlar yöntemi ile analiz yapan Plaxis2D programı kullanarak, farklı aşırı konsolidasyon oranlarına sahip kil zeminlerde yapılan tünellerin deformasyonları incelenmiştir. Tünel modeli Yeni Avusturya Tünel Açma Yöntemi (NATM) kullanılarak oluşturulmuş ve statik ile dinamik yükleme koşullarında kil zemindeki deformasyonlar belirlenmiştir.

Anahtar Kelimeler- Aşırı Konsolidasyon Oranı, Tünel, Kil, Plaxis

1*Sorumlu yazar iletişim: burak.gorgun@bilecik.edu.tr (https://orcid.org/0000-0002-7681-863X) Civil Engineering Department, Bilecik Seyh Edebali Universit, Faculty of Engineering, Bilecik, Turkey 2İletișim: nazile.ural@bilecik.edu.tr (https://orcid.org/0000-0002-2268-842X)

Civil Engineering Department, Bilecik Seyh Edebali Universit, Faculty of Engineering, Bilecik, Turkey 


\begin{tabular}{|c|c|c|}
\hline & $\begin{array}{l}\text { BŞEÜ Fen Bilimleri Dergisi } \\
8(2), 1010-1016,2021\end{array}$ & $\begin{array}{r}\text { BSEU Journal of Science } \\
\text { https://doi.org/10.35193/bseufbd.993806 }\end{array}$ \\
\hline $\begin{array}{l}\text { BiLECIK SEYY EDEBALI } \\
\text { UNIVESITES }\end{array}$ & & 2458-7575 (https://dergipark.org.tr/tr/pub/bseufbd) \\
\hline
\end{tabular}

\section{INTRODUCTION}

Although accidents are less common in tunnels than in open lines, the effects of these accidents are more crucial and vital. Today, it has been faced with a decrease in usage areas for construction according to the globalization. For this reason, some of the road or railroad routes chosen for transportation are passed through underground tunnels.

Osmanoglu [1] studied the tunnels via finite element program Plaxis, which is one of the numerical analysis methods. With this study, the researcher investigated whether a building can be built on the soils where the tunnel exists and the deformations that occur in the tunnel lining. The results obtained were compared by applying soil improvement methods to keep the deformations within acceptable limits. Cortlever and Gutter [2] modeled the design of a set built according to the AuGeo method for the sections of the double railway line proposed in their study. Authors modeled the route, stating that soil improvement works are required to prevent long-term secondary consolidation settlement in the region. Cortlever and Gutter made the basic design according to the British Standard BS8006, which defines the load systems that should be included in the calculations. Finally, the proposed design method is verified with numerical analysis results of Plaxis software. Lahuta and Cihlarova [3] examined the performance analysis of an access road to the existing road network in Ostrava by mathematical modeling with Plaxis 2D. They also stated that this also helped them get feedback on the suitability of the selected measurement method and the effective distribution of the observed points on the structure. Turkoglu [4] analyzed the tunnel collapse in adverse soil conditions using two-dimensional numerical analysis. Turkoglu modeled the tunnel failure mechanism using the finite element method. It was concluded that unforeseen soil conditions would increase deformations significantly due to results. Selman [5] modeled the soil and tunnel excavation stages with the Plaxis program using the finite element method about the effects of excavation stageon the soil behavior of a large single switch tunnel. After the deformations and soil movements obtained, author tried to estimate the building damage with the Burland method. Sandström [6] examined the deformations of the tunnels constructed on London clay with the Plaxis program in his thesis. As a result of analysis, he emphasized that realistic results were obtained in the Plaxis program, but the correct selection of the parameters is very important.

In this study, the tunnel was modeled using the Plaxis2D program, which analyzes the deformations of the tunnels with the finite element method in clay soil conditions with different over consolidation rates. Plaxis is a finite element program, developed for the analysis of deformation, stability, and groundwater flow in geotechnical engineering [7]. In the tunnel model made with the New Austrian Tunneling Method (NATM), deformations in the clay soil under static and dynamic conditions were determined.

\section{MATERIAL-METHOD}

Within the scope of this study, deformations in the clay soil under static and dynamic conditions were determined in the tunnel made with the Austrian New Tunneling Method (NATM). The tunnel was modeled using the Plaxis 2D program according to following application stages. First of all, 3 different boreholes were drilled, and 3 different soil profiles were formed (Figure 1). The terrain model used in the study is presented in Figure 2.

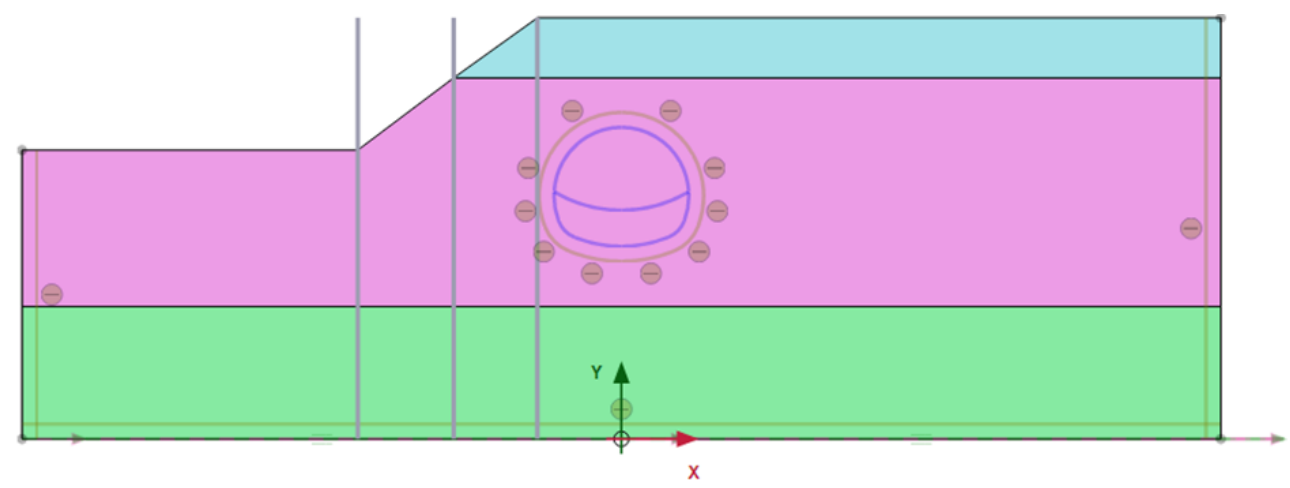

Figure 1. Drilling 


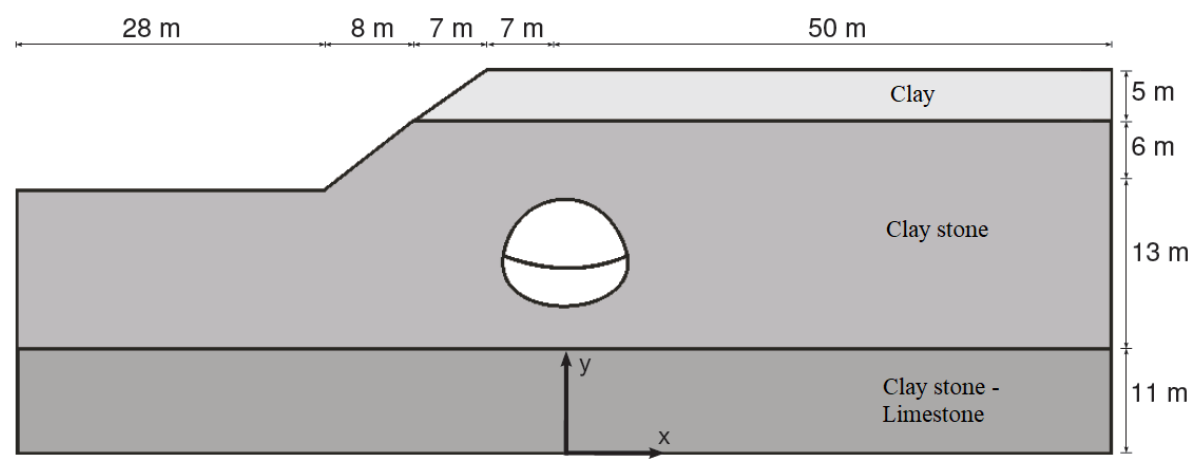

Figure 2. Terrain model

Analyzes were carried out by using the Hoek-Brown method in tunnel construction [8]. The properties of analyzed clay soils are given in Table 1 . The parameters of the soils used in the analyzes were created using the data obtained from the studies by Brinkgreve [9].

Table 1. Clay soil properties

\begin{tabular}{|c|c|c|c|c|c|}
\hline Soil layer & Soil & $\begin{array}{l}\text { Young's } \\
\text { Modulus }\end{array}$ & $\begin{array}{c}\text { Poisson's } \\
\text { Ratio }\end{array}$ & $\begin{array}{c}\text { The } \\
\text { Geological } \\
\text { Strength } \\
\text { Index (GSI) }\end{array}$ & $\begin{array}{c}\text { Uniaxial } \\
\text { compressive } \\
\text { strength } \\
\left(\sigma_{c i}\right)\end{array}$ \\
\hline 1. Layer & Clay & $0.200 \mathrm{E} 6$ & 0.2500 & 10 & $5.00 \mathrm{E} 3$ \\
\hline 2. Layer & Clay stone & $1.000 \mathrm{E} 6$ & 0.2500 & 40 & $25.00 \mathrm{E} 3$ \\
\hline 3. Layer & Clay stone-Limestone & $2.500 \mathrm{E} 6$ & 0.500 & 55 & $50.00 \mathrm{E} 3$ \\
\hline
\end{tabular}

\section{A. Static Conditions}

After the formation of soil layers, the tunnel was created by excavating inside the soil and the interfaces of this tunnel were defined. The properties of the tunnel used in the study are given in Table 2 .

Table 2. The properties of the tunnel

\begin{tabular}{cc}
\hline Parameter & Lining \\
\hline Stiffness $(E A)$ & $6.0 \times 10^{6} \mathrm{kN} / \mathrm{m}$ \\
Flexural rigidity $(E I)$ & $2.0 \times 10^{4} \mathrm{kNm} / \mathrm{m}$ \\
Weight $(w)$ & $5.0 \mathrm{kN} / \mathrm{m} / \mathrm{m}$ \\
Poisson's ratio $(v)$ & 0.15 \\
\hline
\end{tabular}

Two different excavation procedures were carried out to prevent collapse during the tunnel excavation. In the first stage, the upper part of the tunnel was excavated and in the second stage this part was concreted. In the 3rd stage, the lower part of the tunnel was excavated, and this part was concreted in the 4th stage. After the land was divided into meshes to be used in the finite element method, the deformations at each stage were determined (Table 3) (Figure 3). 


\begin{tabular}{|c|c|c|}
\hline & $\begin{array}{l}\text { BŞEÜ Fen Bilimleri Dergisi } \\
8(2), 1010-1016,2021\end{array}$ & $\begin{array}{r}\text { BSEU Journal of Science } \\
\text { https://doi.org/10.35193/bseufbd.993806 }\end{array}$ \\
\hline v & & 2458-7575 (https://dergipark.org.tr/tr/pub/bseufbd) \\
\hline
\end{tabular}

Table 3. Deformations during tunnel construction

\begin{tabular}{cc}
\hline Stages & Deformation (mm) \\
\hline $1^{\text {st }}$ stage (tunnel top excavation) & 2.818 \\
$2^{\text {nd }}$ stage (tunnel top concreting) & 4.070 \\
$3^{\text {rd }}$ stage (Tunnel sub-excavation) & 4.644 \\
$4^{\text {th }}$ stage (tunnel sub-concreting) & 4.592 \\
\hline
\end{tabular}

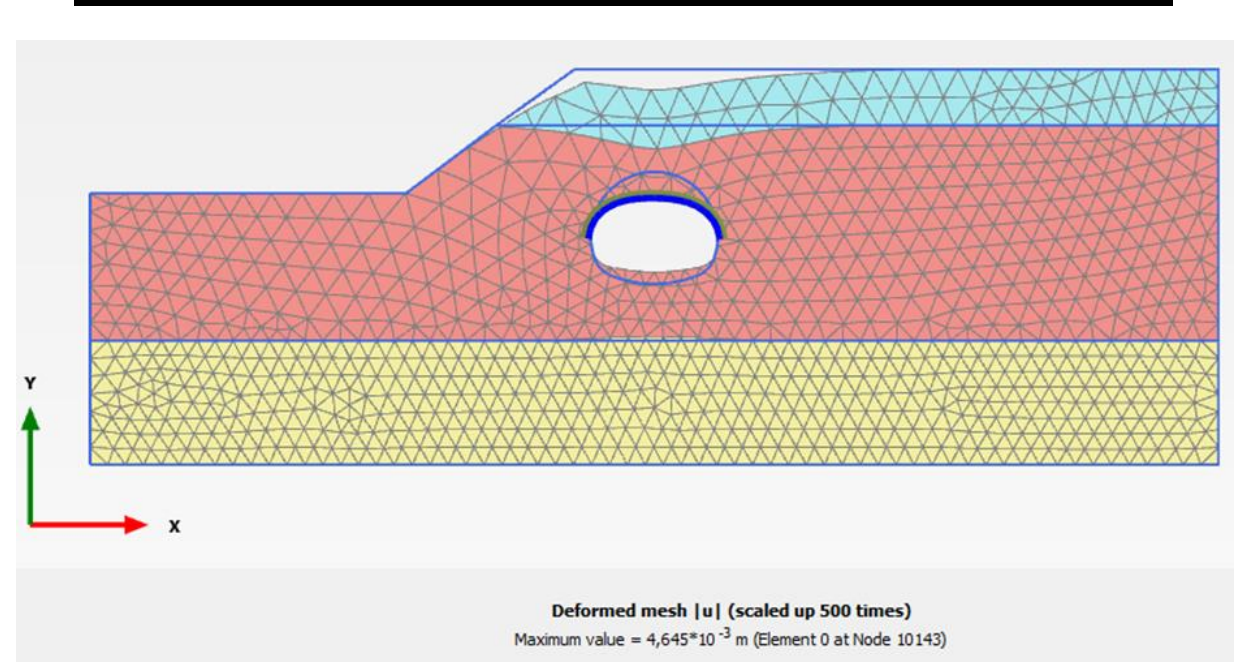

Figure 3. The deformation of tunnel construction

\section{B. Dynamic Conditions}

After the completion of the tunnel construction, whose deformations were determined under static conditions, the acceleration of the earthquake which has a 5.4local magnitude (Ml) (Figure 4) was applied to the tunnel in the $\mathrm{x}$ and $\mathrm{y}$ axes (horizontal and vertical) and with the calculation method in the time-history analysis, the displacements of the tunnel were found under dynamic conditions (Table 4).The time-history acceleration graph is from Bentley Systems, the official company of Plaxis.

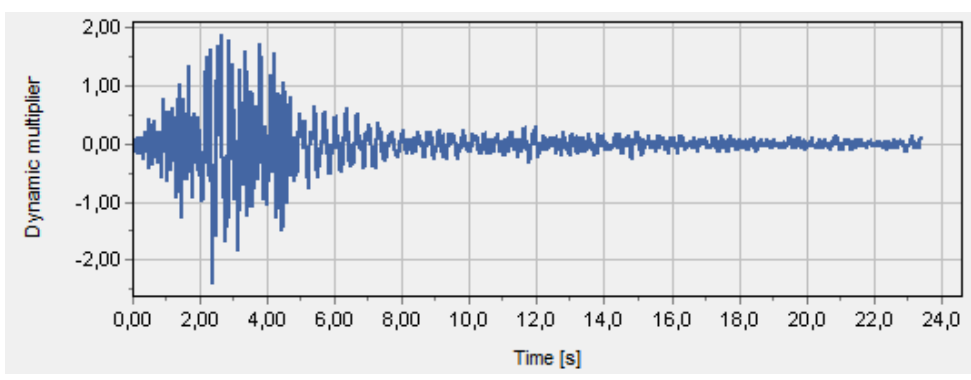

Figure 4. Time-history acceleration graph

Table 4. Deformations due to dynamic loading

\begin{tabular}{cc}
\hline Direction & Deformation (mm) \\
\hline $\mathrm{X}$ & 74.27 \\
$\mathrm{Y}$ & 33.16 \\
\hline
\end{tabular}




\section{RESULTS AND DISCUSSION}

In the scope of the study, the effect of over consolidation ratio on the tunnels that built in clay soils, was investigated. Ladd and Foott [10] investigated the change of normalized undrained shear strength with over consolidation ratio in their study using 5 different types of clays. The authors observed that the undrained shear strength increased as the over consolidation ratio increased (Figure 5). Drained shear strength in clays is determined as " $c_{u}=q_{u} / 2 "$ [11]. Thus, in order to use different over consolidation ratios, analyzes were carried out using clay soils with uniaxial compressive strength (Table 5).

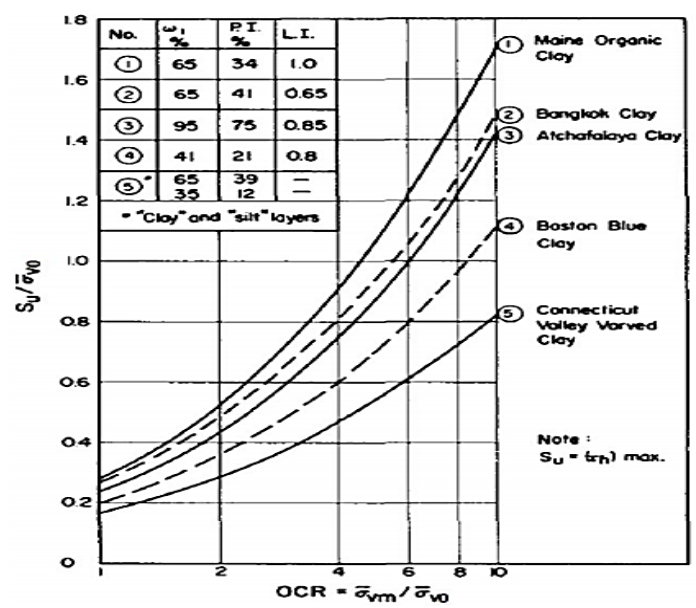

Figure 5. Relation of shear strength-over consolidation ratio

Table 5. Properties of soils used in analysis

\begin{tabular}{ccccc}
\hline Analysis & $\begin{array}{c}\text { Young's } \\
\text { Modulus }\end{array}$ & $\begin{array}{c}\text { Poisson's } \\
\text { Ratio }\end{array}$ & $\begin{array}{c}\text { The } \\
\text { Geological } \\
\text { Strength } \\
\text { Index }(\text { GSI })\end{array}$ & $\begin{array}{c}\text { Uniaxial } \\
\text { compressive } \\
\text { strength }\left(\sigma_{\mathrm{ci}}\right)\end{array}$ \\
\hline $1^{\text {st }}$ analysis & $1.000 \mathrm{E} 6$ & 0.2500 & 40 & $25.00 \mathrm{E} 3$ \\
$2^{\text {nd }}$ analysis & $1.000 \mathrm{E} 6$ & 0.2500 & 40 & $5.00 \mathrm{E} 3$ \\
$3^{\text {rd }}$ analysis & $1.000 \mathrm{E} 6$ & 0.2500 & 40 & $50.00 \mathrm{E} 3$ \\
\hline
\end{tabular}

Table 6.

As a result of the analyzes made, the deformations that occur during tunnel construction are given in

Table 6. Deformations during tunnel construction

\begin{tabular}{cccc}
\hline Analysis & $\mathbf{1}^{\text {st }}$ analysis & $\mathbf{2}^{\text {nd }}$ analysis & $\mathbf{3}^{\text {rd }}$ analysis \\
\hline Stages & & Deformation (mm) & \\
\hline $1^{\text {st }}$ stage (tunnel top excavation) & 2.818 & 4.530 & 2.610 \\
$2^{\text {nd }}$ stage (tunnel top concreting) & 4.070 & 6.427 & 4.018 \\
$3^{\text {rd }}$ stage (tunnel sub-excavation) & 4.645 & 748.000 & 4.127 \\
$4^{\text {th }}$ stage (tunnel sub-concreting) & 4.592 & - & 4.250 \\
\hline
\end{tabular}

When the results of the soils used in the 1st and 3rd analyzes investigated, it was observed that deformations during tunnel construction decreased with the increase of uniaxial compressive strength due to the over consolidation ratio. In the clay soil used in the second analysis, due to the low over consolidation ratio, high amount of deformations occurred in the tunnel bottom excavation, which was the 3rd stage during the tunnel construction, and this caused the collapse of the soil (Figure 6). 


\begin{tabular}{|c|c|c|}
\hline & $\begin{array}{l}\text { BŞEÜ Fen Bilimleri Dergisi } \\
8(2), 1010-1016,2021\end{array}$ & $\begin{array}{r}\text { BSEU Journal of Science } \\
\text { https://doi.org/10.35193/bseufbd.993806 }\end{array}$ \\
\hline ERS & & 2458-7575 (https://dergipark.org.tr/tr/pub/bseufbd) \\
\hline
\end{tabular}

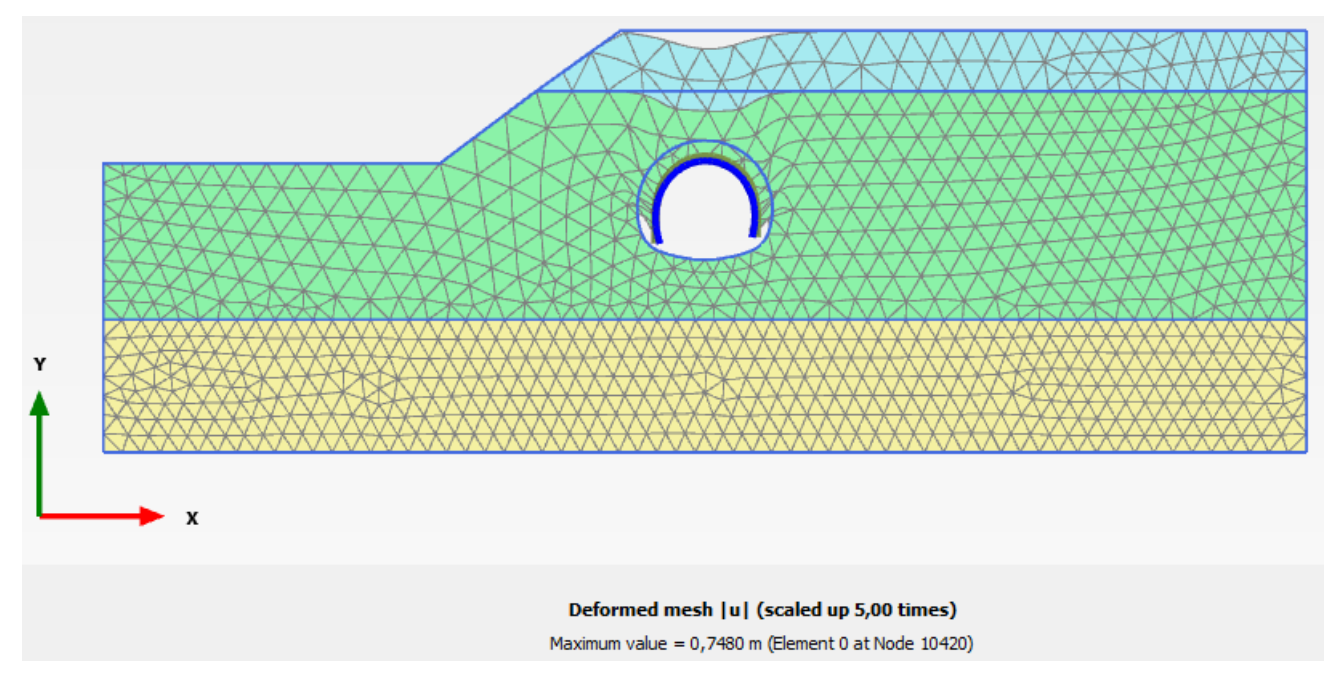

Figure 6. Soil collapse during tunnel bottom excavation in the $2^{\text {nd }}$ analysis

The deformations that occur under dynamic loading conditions in the $1^{\text {st }}$ and $3^{\text {rd }}$ analyzes, are given in Table 7. According to that, it was observed that the deformations decreased although there was not much difference in the case of dynamic loading with the increase of the over consolidation ratio. As a result of the dynamic analysis, it was observed that horizontal displacements are higher in tunnels compared to vertical displacements.

Table 7. Deformations under dynamic loading conditions in the $1^{\text {st }}$ and $3^{\text {rd }}$ analysis

\begin{tabular}{ccc}
\hline Analysis & $\mathbf{1}^{\text {st }}$ analysis & $\mathbf{3}^{\text {rd }}$ analysis \\
\hline Direction & \multicolumn{2}{c}{ Deformation $(\mathrm{mm})$} \\
\hline $\mathrm{X}$ & 74.27 & 61.12 \\
$\mathrm{Y}$ & 33.16 & 22.83 \\
& & \\
\hline
\end{tabular}

\section{CONCLUSION}

In this study, the tunnels were modeled using the Plaxis2D program, which analyzes the deformations of the tunnels with the finite element method in clay soil conditions with different over consolidation ratios. Thus, deformations that may occur under static and dynamic conditions in clay soils with different consolidation ratios were determined. As a result of the studies, when the analysis made in the soils were examined, it was observed that the deformations during the tunnel construction decreased with the increase of uniaxial compressive strength due to the over consolidation ratio. Although there was not much difference in the case of dynamic loading conditions, it was observed that with the increase of the over consolidation ratio, the deformations were decreased. In addition, as a result of dynamic analysis, it was observed that the horizontal displacements in the tunnels are higher than vertical displacements.

\section{REFERENCES}

[1] Osmanoglu, D. (2007). Analysis of Soil Improvement and Soil Stability for Tunnel Construction by Using Plaxis Software and Finite Elements Method. Master of degree. Istanbul Technical University Institute of Science and Technology.

[2] Cortlever, N. G., \& Gutter, H. H. (2002). Design of double track railway Bidor-Rawang on AuGeo Piling System according to BS8006 and PLAXIS numerical analysis. In Proc. of the 4th Int. Conf. on Ground Improvement Techniques, 26-28.

[3] Lahuta, H., \& Cihlarova, D. (2012). Experience with mathematical modeling in program plaxis: design and assessment of retaining walls. In: $12^{\text {th }}$ International Multidisciplinary Scientific GeoConference. SGEM., 8794.

[4] Türkoglu, M. (2013). Two-dimensional numerical analysis of tunnel collapse driven in poor ground conditions. Master of degree. Middle East Technical University Institute of Science. 
[5] Selman, H. G. (2014). Soil Movements Induced by Tunneling and Their Effects on Existent Building. Master of degree. Istanbul Technical University Institute of Science and Technology.

[6] Sandström, M. (2016).Numerical Modellingand Sensitivity Analysis of Tunnel Deformations in London Clay. Master of degree. Stockholm University.

[7] Brinkgreve, R. B. (2018). Plaxis 2D Manuals: Tutorial Manual, Reference Manual, Material Models Manual, Scientific Manual. Delft University of Technology and Plaxisbv., 978(90), 76016.

[8] Hoek, E., \& Brown, E. T. (1997). Practical estimates of rock mass strength. International Journal of Rock Mechanics and Mining Sciences, 34(8), 1165-1186.

[9] Brinkgreve, R. B. (2005). Selection of soil models and parameters for geotechnical engineering application. Geo-Frontiers Congress 2005. January 24-26, 2005. Austin, Texas, United States, 69-98.

[10] Ladd, C. C., \& Foott, R. (1974). New design procedure for stability of soft clays. Journal of Geotechnical and Geoenvironmental Engineering, 100, 10064.

[11] Terzaghi, K., Peck, R. B., \& Mesri G. (1967). Soil Mechanics in Engineering Practice. John Wiley \& Sons. Inc. 